\section{THE EMERGENCE AND THE WAY OF LIFE OF THE WAGE LABORER CLASS IN THAILAND FROM THE END OF THE $18^{\mathrm{TH}}$ TO THE $19^{\mathrm{TH}}$ CENTURY ${ }^{1}$}

\section{Punnee Bualek ${ }^{2}$}

\begin{abstract}
This research explores the answers to three significant questions. 1) When and in what conditions did the wage laborer class emerge in Thailand? 2) What kinds of relationships were there between the wage laborers and the productivity process? 3) Under those relationships, what were their real lives and way of life like?
\end{abstract}

The first groups of hired laborers in Thailand were Chinese coolies, the outsiders of the "phrai" system. To study this laborer group, we should understand four inter-related factors. The first are the problems within China that pushed Chinese emigrants from their homeland. The second are the trading and production changes in Southeast Asia, which came from many factors both inside and outside the region. The third is the power of Western countries, which influenced Southeast Asia at that time. The fourth are the conditions and problems in Thai "sakdina" society, including the political

\footnotetext{
${ }^{1}$ The research project on which this article is based was financially supported by The Thailand Research Fund (TRF).

${ }^{2}$ Associate Professor, Graduate School, Krirk University, Bangkok, Thailand
}

and governmental institutions, which were changed in King Rama V's reformation.

The research found that the laborer class in Thailand emerged at the end of the $18^{\text {th }}$ century in a situation where production for export and trade prospered. They were all Chinese laborers. They used the "kongsi" system in their community and in their ways of production. Moreover, they used the "kongsi" system for trading and protecting themselves from outsiders. The "kongsi" system had a horizontal relationship that emphasized brotherhood, partnership and equality among its members. Later on, this system was superseded by the triad system, which was a vertical relationship. The triad, or T'ien-ti Hui, or secret societies, were governed by a hierarchy and had strict rules, so in this organization equality disappeared. Its ritual oath-taking ceremony and use of opium made the triads tightlyknit. Consequently, coolies and employers could not be separated within the triad "kongsi" system. Coolies would be well taken care of if they demonstrated loyalty to and worked hard for their employers, but they would be severely punished if they lacked these qualities.

This research draws a clear picture of the coolies' lives in the early Rattanakosin period to the beginning of King Rama VI, in the shipping and the ship-building industry, the sugar industry, pirate organizations, tin mines and various economic activities in the capital, Bangkok.

The triad "kongsi" system gradually faded out at the end of the $19^{\text {th }}$ century when there were many changes in Thai society brought about by both Western influences and the attitude of the Thai government. At that time, Bangkok became the hub of 
export production. After that, the triad "kongsi" system was not suited to the urban way of life in a modern city such as Bangkok. The employers or the rich were the first to separate themselves from the "kongsi" system. Some of them moved to become aristocratic Thai. They absorbed both Western and Thai "sakdina" culture and then neglected the "kongsi" Chinese culture. They established, instead, new organizations like merchant guilds and chambers of commerce. These groups of merchants were called "thaokae." At the same time, the coolies themselves established their new organizations, which subsequently became the modern laborer organizations. At first, the coolie organizations were controlled by "thaokae" groups who employed them for their own advantage. These kinds of organizations were "angyi" or gangsters, which were latterly subdued by the Thai government towards the end of King Rama $V$ 's reign and the beginning of King Rama VI's reign.

\section{Introduction}

This paper is a brief account of research that studied the kongsi system and the laborer class in Thailand. The concept of the Chinese kongsi system that is used in this research comes from three important historical works. The first one is The Origins of Chinese Kongsi by Wang Tai Peng, which tries to explain the origins and erosion of the kongsi system in Southeast Asia (Wang 1995). Another item of research is Opium and Empire: Chinese Society in Colonial Singapore 1800-1990 by Carl A. Trocki. He describes the kongsi system of Singapore and Southeast Asia (Trocki 1990). The third source is Chinese Pioneers on the Sarawak Frontier 1841-1941 by Daniel
Chew, in which he specifically studies the kongsi system in Sarawak (Chew 1990).

The three works are different when explaining the characteristics of the kongsi system but they are similar in explaining their establishment and ruin. Moreover, they emphasize that the kongsi system were almost inevitable for most overseas Chinese as is shown by their establishment in Borneo by the Hakka from the end of the eighteenth until the end of the nineteenth century. Trocki does not entirely agree with many points in Wang Tai Peng's kongsi concept that the kongsi system which appeared in Southeast Asia were unique in their combination of the Chinese brotherhood tradition within an economic partnership and that the kongsi system of Southeast Asia were different from the "secret" societies of China. Trocki explains that the Chinese kongsi systems were organized for economic purposes. They emerged in the eighteenth century within Chinese settlements in Southeast Asia and they were primarily workers' organizations. Some of them were characterized by some forms of triad ritual and could thus be considered as "secret" societies. Trocki argues that the kongsi systems of Southeast Asia were not unique. Particular circumstances led to different kongsi configurations. In certain situations, kongsi ties based on kinship or speech group or regional origin cut across oaths of brotherhood. The significance of the kongsi systems was their economic function. The Kongsi system grew up around certain occupations and industries, in different places and at different times, and they maintained a variety of relationships with external political structures. Likewise, whether or not a kongsi system was a "secret" society was largely a function of its situation. Rituals were probably always private but in 
situations where the kongsi system was not a forbidden organization secrecy was probably only a formality.

Trocki explains that the kongsi systems in Southeast Asia and in some colonies did not always form a self-governing community but, rather, some were under the power of local government. The kongsi systems were thus economic organizations that assumed the functions of government when necessary. Some kongsi systems lacked democracy and equality. The triad concept of brotherhood, the "heaven-earthman," seems to have formed the umbrella, particularly in frontier situations. Some kongsi systems had political and military aspects. The early settlements of the overseas Chinese were an extension of the maritime world dominated by antiManchu rebels. The settlers came in ships or as groups, perhaps already organized as kongsi. Another reason for maintaining the military-political function was that these overseas settlements had to provide their own defense in a relatively hostile and unsettled environment. Even where a reliable local government provided security, the Chinese were generally left to manage their own internal affairs. These were undertaken by the kongsi system.

Even though there have been some historical studies portraying the economic and social changes in the early Rattanakosin period, the story of wage laborer class in Thailand is still unclear. The three major works on the topic are Chinese Society in Thailand: An Analytical History by William Skinner, (Skinner 1957) Tribute and Profit: SinoSiamese Trade 1631-1853 by Sarasin Viraphol (Viraphol 1977) and Pak Kai Lae Bai Rua by Nithi Iawsriwong (Iawsriwong 1995). Skinner generally studies Chinese society in Thailand. The pictures that he distinctly displays are the story and statistics of Chinese immigrants. Viraphol's work emphasizes the trade between Siam and China from its prosperity to its decline. Iawsriwong studies Chinese immigrants as Siam's bourgeois class and their activities in both foreign and inland trade. These three do not study Chinese activity in production and consequently the story of laborers is only inexplicitly shown.

The three works of Wang Tai Peng, Carl A. Trocki and Daniel Chew have been used to provide the conceptual framework for this research in studying the circumstances and conditions of the wage laborer class in Thailand. The study can be outlined as follows.

1. Chinese coolie immigrants formed the first group of the wage laborer class in Thailand. This class originated in sakdina society at the end of the eighteenth century co-inciding with the end of the Ayutthaya and the beginning of the Rattanakosin periods. During the reigns of King Rama I to King Rama III of the Rattanakosin Period, they developed as an exclusive class in Thai society. Chinese coolies worked at first in the shipping and the ship-building industry, in pepper plants and the sugar industry and later in tin mines, rice mills and saw mills. All of these were part of the export business and had the Chinese merchants as the real employers. In some businesses, Chinese merchants had to deal under the umbrella of members of the Thai upper class who facilitated their activities by lending capital or giving extra legitimacy. In the nineteenth century, some Chinese coolies worked in the public works of the modern city of Bangkok replacing the phrai corvee laborers. 
The arrival of Chinese coolies coincided with a period of expansion in commerce and a high demand for laborers in Southeast Asia. At that time, the forced corvee laborers or phrai people were under the control of the Thai sakdina ruling class. The demand for commodities in Southeast Asia came from 2 areas; 1. China demanded tin, gold, tobacco, gambia, pepper, sugar, rice and forest commodities. 2. Europe demanded coffee, sugar, pepper, teak, rice and forest commodities. Some of this demand could not be satisfied or afforded by the phrai people, so the Chinese stepped in and the Thai ruling class did not despise them because the rulers derived advantages from exporting and trading taxes including internal production revenue.

Iawsriwong (1995) comments that Chinese immigrants in the Early Period of Rattanakosin were populations with quality, diligence and a tolerance for hard work. Moreover, they had some economic experience and commercial knowledge especially in accounting. Nevertheless, most of them failed to achieve success in both social and economic status in their society. They were all uneducated so they were unable to be good delegates of Chinese culture. The work that they could do and which made the Thai higher class admire them was as craftsmen, builders, artists and masons (Swee 1991: 37-48).

2. There were four reasons why the Chinese coolies migrated to Thailand. 
Table 1: Selected estimate of the Chinese and total population of Thailand prior to 1917

\begin{tabular}{|c|c|c|c|}
\hline $\begin{array}{c}\text { Approx. } \\
\text { Year }\end{array}$ & Chinese & $\begin{array}{c}\text { Total } \\
\text { (all races) }\end{array}$ & Source \\
\hline 1822 & 440,000 & $2,790,500$ & Crawfurd 1830, II. 224 \\
\hline 1827 & 800,000 & $3,252,650$ & Mallock 1852, 73 \\
\hline 1835 & 500,000 & $3,620,000$ & Edmund Roberts, from Malcom 1839, 146 \\
\hline 1839 & 450,000 & $3,000,000$ & Malcom 1839,145 \\
\hline 1849 & $1,100,000$ & $3,653,150$ & Mallock 1852, 73 \\
\hline 1854 & $1,500,000$ & $6,000,000$ & Pallegoix 1854, I, 8 \\
\hline 1858 & - & $5,000,000$ & Auguste Heurtier, from Girard 1860, 5 \\
\hline 1862 & $1,750,000$ & $7,000,000$ & Werner 1873,259 \\
\hline 1864 & - & $4,000,000$ & Siam Consular Report 1864 \\
\hline 1878 & $1,750,000$ & $7,750,000$ & Rousset 1878,106 \\
\hline 1885 & $1,500,000$ & $5,900,000$ & Rosny 1885,116 \\
\hline 1890 & $3,000,000$ & $10,000,000$ & Gaston Rautier, from Hallett 1890, 461 \\
\hline 1891 & 500,000 & - & Gordon 1891,289 \\
\hline 1892 & $1,500,000$ & $5,900,000$ & Hoeylaerts 1892,10 \\
\hline 1894 & 900,000 & $9,000,000$ & Directory for Bangkok and Siam 1984, 8 \\
\hline 1900 & 400,000 & - & Campbell 1902, 268\# \\
\hline 1900 & 600,000 & - & Raquez 1903, 434 \\
\hline 1903 & 700,000 & $5,000,000$ & Little 1903, 261 \\
\hline 1903 & $2,000,000$ & $6,300,000$ & Mury 1903,54 \\
\hline 1903 & $2,500,000$ & - & Gottwaldt $1903,75,89$ \\
\hline 1903 & 480,000 & $5,029,000$ & Directory for Bangkok and Siam 1903, 119** \\
\hline 1907 & $1,400,000$ & $6,000,000$ & Siam Free Press 1907 \\
\hline 1907 & $2,755,807$ & - & "Statistik der Chinesen in Auslande" 1907- \\
\hline 1910 & $1,200,000$ & - & 1908,277 \\
\hline 1912 & 400,000 & $6,020,000$ & Survey of Chinese Industry and Commerce \\
\hline 1912 & 650,000 & - & 1951 Graham 1912,109 \\
\hline 1916 & $1,500,000$ & - & $\begin{array}{l}\text { China Year Book 1912, } 35 \\
\text { China Year Book 4916, } 37\end{array}$ \\
\hline
\end{tabular}

(Skinner 1957: 68-69)

2.1 Starvation and political problems encouraged Chinese migration, especially among the people who lived near the South Seas (Nanyang). China had always faced many natural hazards: floods, the collapse of dams, epidemics, high temperatures and droughts. These problems made the cultivation of crops far more difficult and, with lower yields, many people died of starvation. As well as natural hazards, the lives of many Chinese people were made worse by wars, both internal and from outside which not only lowered productivity but also used up any surplus. Wars with foreign countries cost an enormous amount and the Chinese community was severely hampered by having to pay war debts. Moreover, as an additional burden, many Chinese were 
oppressed by foreigners. Wholesale starvation brought about by economic, political, natural and social problems made many people in the south of China migrate from their homeland. Even though the Ch'ing Governments did not permit this practice, and considered those leaving to be pirates, criminals or traitors, many Chinese continued to migrate to the South Seas for their survival and to make their fortune (Iawsriwong 1995: 145-146).

2.2 In the nineteenth century, Chinese laborers were in great demand on the world market and the Ch'ing dynasty was forced to change its policy of prohibiting its people from migrating to one of protecting its people who were working as wage laborers, or "coolies." In this century, some Western countries, in extending their power and economic activity in their colonies, found that they needed many more unskilled laborers to help in the extraction of the colonies' natural resources. In 1838, the American government passed an act to prohibit the African slave trade. One of the results was that Chinese laborers, working for low wages, replaced black slave laborers in some economic activities. In the nineteenth century, Penang, Singapore, Macao and Hong Kong became the trade centers for Chinese coolies in Southeast Asia (Irick 1982: 6-8). The traffic of Chinese coolies made a lucrative profit for some Portuguese, British and French companies. After the end of the Opium War in 1845, the coolie trade began to expand but it was abolished in 1874, following strong Chinese opposition to the practice (Yen 1985: 119, 122).

Chinese coolies were exported to all regions of the world; to South Africa, to North and South America and to almost every area in Southeast Asia. In general,
Chinese coolies were either: 1 . voluntary immigrants, 2. indentured coolies, or 3. credit-ticket coolies. The voluntary immigrants, or free emigrants, went abroad bypassing any local and foreign coolie dealers so they were free to work when they arrived at their destination. This group of coolies normally had relatives or friends to accommodate them. The indentured and the credit-ticket coolies migrated under the control of coolie dealers as part of the coolie trade system. The indentured coolies received money when they arrived at their destination and then the coolies were passed into the hands of the coolie dealers. At the port, the coolies could be sold on to other dealers at a high profit. The other group, the creditticket coolies, had no money to pay for their tickets. When they arrived at their destination, there would be someone to pay for their tickets including any expenses incurred on the voyage and after this payment was made, the laborers were free to work. Normally both indentured coolies and credit-ticket coolies were treated similarly. They were treated like animals and were called "pigs" because of the disgusting conditions on the ships. Almost all of them worked hard for their freedom which, on average, they secured after three years (Campbell 1971: 2-6).

The coolies that migrated to Thailand were of two kinds: voluntary immigrants and credit-ticket coolies.

The coolie trade in China was managed by both foreign coolie brokers and local brokers. In this situation, the Ch'ing dynasty's policies for prohibiting the coolie trade and Chinese people from going abroad, were not successful. After the Treaty of Beijing in 1860, the Ch'ing dynasty had to accept the existence of the coolie trade and had to change its policies 
to protect Chinese people who were going abroad. Under the government's new policy toward the coolie trade, Chinese people legally migrated in order to work abroad. This new policy was brought about by the pressure exerted upon the Ch'ing government by those powerful countries that had most to benefit from the coolie trade. In addition, the Ch'ing government recognized the economic capability of the Chinese working overseas writing overseas and anticipated that considerable funds would be sent back to China (Swee 1991: 66-69). The new attitude and policy toward coolies augmented the coolie traffic so that cheap Chinese laborers were soon to be found everywhere in the world.

2.3 The court of Siam had for a long time accepted Chinese people as migrants into the kingdom. Many Chinese people had migrated into this kingdom from the beginning of the Ayutthaya period. They played a significant role in shipping by becoming accountants, storehouse officials and sailors. Many others worked as merchants, pig farmers, craftsmen, traditional Chinese dancers, state officials and doctors, to name but a few. There were three reasons that Thai society had relied on them and had left important work in their hands. 1. The Chinese had become accustomed to both the Thai people and the Thai court. Opportunities for trade prompted further immigration to Thailand and many Chinese became long-term residents. 2 . The Chinese court and the Siamese court had a close relationship because the Siamese court accepted traditional Chinese trade under the tribute system. The trade between the two countries was prosperous in the reigns of King Rama II and King Rama III. 3. Chinese immigration did not trouble the Siamese state, but rather satisfied the need for laborers, tax farmers, loyal ship's officers and craftsmen.

Because of the large number of Chinese immigrants entering the country, the Siamese court introduced laws to control the flow. In the reign of King Rama II, Chinese immigrants were controlled by the collection of a poll tax generally known as phuk phi. Every three years they had to register with the state for phuk phi and they had to pay two baht with a fee of one satang. This payment was increased in the reign of King Rama III to four baht with a fee of one satang. This rate of payment continued to be used until King Rama V abolished it in 1908 and changed it to correspond with the same rate that Thai people paid which was six baht a year from 1909. This method provided some means of controlling the number of Chinese immigrants. The Siamese state instituted some Chinese governors in the reign of King Rama III and some Chinese judges in the reign of King Rama IV. Siamese state policy towards Chinese immigrants was to permit some limited Chinese self-governance, one result of which was to increase the number of Chinese people migrating to Thailand (Lertphanichkul 1991: 117-130).

2.4 The ease of traveling from China to Thailand also encouraged greater Chinese migration. At first, the Chinese often migrated in Chinese junks. The Teochiu dialect group was the most numerous migrant group coming into Thailand on their red-hulled junks from the port of Zhanglin port. Many Hokkien dialect people sailed from Fukien in their green-hulled junks. The voyage generally took more than a month. The junk weighed about three hundred fifty tons and had usually no fewer than two hundred passengers. The Chinese junk journey was 
dependent upon wind. For the journey to Thailand, ships had to come between January and April to take advantage of the north-eastern monsoon. The return trip to China was best undertaken in June or July, helped by the south-western monsoon. The passengers had to live their normal everyday lives on the deck of the junk for a long period of time and they also had to face shortages of food and water, problems with pirates and the vagaries of the weather (Chanthawanich 1991: 13-15).

About the middle of the nineteenth century, there was a change in marine transportation. Westerners brought steamships for transportation to every important port of this region including China, Singapore, Hong Kong, Amoy, Kwangtung and Swatow. Steamships were employed instead of the Chinese junks because they were better able to accommodate the enormous increase in coolie traffic after the end of the Opium War and the Beijing Treaty of 1860 that allowed Chinese people to go abroad legally. The lucrative profit from the Chinese coolie traffic attracted Western Shipping companies and their interest grew in this business.

In 1873, The Scottish and Oriental Company began to use steamships for voyages between Bangkok, Hong Kong and Swatow and, also, appointed the Windsor Company its agency in Thailand. Initially, shipping schedules were not very accurate but, at the beginning of 1882, the Bangkok Passenger Steamer Company of Britain began to run the shipping business between Bangkok and Swatow and the company inaugurated a punctual once-aweek schedule. Subsequently, other rival European ship companies entered the business and, in 1888, a new line providing a direct voyage between
Bangkok, Swatow and Hainam was opened so that Chinese coolies could be more expeditiously transported to Thailand (Veeskul 1949: 2-5).

Among the Western countries, Britain had been the one that had taken most advantage of the coolie traffic to Thailand at first but in 1874-1899 the British steamship companies faced rivalry from Norwegian and German shipping companies. From 1899, Germany became the most powerful country in shipments to the Far East and Southeast Asia. This success occurred because of the assistance of the German government, which strongly supported their shipping companies in the competition. The North German Lloyd Steamship Company took over the British ship companies and controlled fifty five percent of the shipping into and out of Thailand. After the German shipping companies had eliminated their rivals, they raised the ticket price. In 1906 the Nippon Yusen ship company of Japan launched their business in Thailand but for a short period the company had to withdraw because of failure in the face of reduced ticket price competition. For this reason, the German shipping companies continued to control all shipments to and from Thailand

In 1908, some Chinese merchants in Thailand tried to destroy the shipping monopoly and the high price of traffic. They collaborated to establish a new shipping company, the "Siam Chinese Ship Company," by hiring some steamships from a Norwegian company. The company had many shareholders from the leaders of five Chinese dialect groups: Hokkien, Teochiu, Hakka, Hainam and Kwangtung. Moreover, some of the shareholders such as Mr. Hun Kim Hoad, Mr. Aung Lum Sum and Mr. Seow Hood 
Seng, had connections with the national party "Guomingdang" of China. The attempt to establish their shipping company came from the growing feeling of nationalism among Chinese leaders, who wished to strengthen their nation and to counter Western influence. Even though the Chinese leaders and merchants compelled their employees to take the company ship when they went abroad, the company met with failure like the other European companies that had previously been rivals in this business. At last, the Siam Chinese Ship Company was abolished in 1912. Some important shareholders like Kim Seng Lee (Luang Sophon Phet Charat) and Yi Koh Hong (Phra Anuwat Ratchaniyom), were left in debt and bankruptcy followed. As a result, the Thai shipping business remained under the control of a few German shipping companies (Bualek 2002: 52-56).

3. The kongsi system emerged in Southeast Asia at the end of the eighteenth and the beginning of the nineteenth century. This system was not only a commercial relationship but also the basis of all Chinese coolie immigration relationships. The kongsi system initially emphasized brotherhood and partnership with equality but later this system was superseded by the triad or "Tien-ti Hui" which was familiarly called a secret organization or angyi in some areas. In Thailand this kind of organization may have begun at the same period as in other parts of Southeast Asia but it explicitly showed up at a tin mine in the south of Thailand during the reign of King Rama II of the Rattanakosin period (Lertphanichkul 1981: 144). At that time there were a lot of Chinese coolie immigrants in both agricultural plantations and tin mines so the triads were needed to oppress the coolies and crush any resistance. According to the evidence, in 1824 during the reign of King Rama III in Chanthaburi province, a Teochiu bean-oil kongsi system with 700-800 members fought against a Hokkien kongsi system. Both of them had an established triad system which had the managers of the mills called long chu as leaders of the triads (Damrong Rachanuphap 1974: 328$331)$.

As well as setting up the triad kongsi system, the use of opium became a highly significant instrument for intoxicating coolies to persuade them to work hard and not escape. One of the major problems of the governments of King Rama II and King Rama III was that the triad kongsi system provided opium for coolies and smuggled large quantities of opium into the country. Even though King Rama III introduced a prohibition policy for opium possession and addiction and proclaimed that those who broke it would be severely punished, opium smuggling remained prevalent. This policy failure was caused by three main factors. 1. The Thai government realized that Great Britain was the nation that derived most benefit from the trade and was behind-the-scene in supplying opium; in this area the Thai government dared not oppose Britain. 2. Many Thai aristocrats lacked honesty and benefited from the smuggling of opium, so the attempts to suppress opium in the reign of King Rama III were unsuccessful. 3. Opium consumption was an ingrained habit with many coolies and thus it was impossible to stamp out the habit. The more Chinese coolies migrated to Thailand, the more opium was distributed in this country (Damrong Rachanuphap 1974: 332-338).

Because it proved impossible to suppress the growing opium trade, a royal 
command in 1851 sanctioned opium addiction with the government benefiting from future taxes on its sale. However, the defeat of China by Great Britain in the Opium War was significant. China had to pay both money and land as an indemnity for the war. This was a clear lesson for the Thai state. By the terms of the Bowring Treaty 1855 between Thailand and Great Britain, there was an agreement that Great Britain could import opium into Thailand without any tax, hence the number of opium distributors in the country grew considerably. The opium tax that the state derived from the tax-farmers represented one quarter (1-4) of the nation's entire higher income-derived from opium, lotteries, gambling and distillation taxes. The proportion of taxes from the consumption of the coolies was about fifty per cent of the entire revenue collection, twenty per cent of which came from opium (Jaranpattana 1980: 102-103, 172173).

The kongsi system controlled the coolies' ways of living for about one hundred years from the end of the eighteenth century but it faced a decline at the end of the nineteenth century at the end of King Rama V's reign and the beginning of King Rama VI's reign. The cause of the decline was principally that the fraternal relationship in the kongsi system gradually deteriorated and was replaced by the employee/employer relationship. Furthermore, the environment of the coolies' lives between the beginning and the end of the nineteenth century was of the significantly different. By the end of the nineteenth century, Bangkok, a modernized capital with many new roads for transportation, was becoming the center of production. It was isolated like the production areas in the Early Rattanakosin Period. The relationship between employers, between thaokae people, and the employees changed. Most of thaokae people resided in luxurious European-style residences in town, so they did not stay in the kongsi houses with the coolies any more. The kongsi houses were the homes of the coolies and the Chinese managers or long chu. Some of the employers began to adopt European culture and enjoyed Thai sakdina rank by becoming tax-farmers, so the essence of the kongsi system that emphasized a closed fraternal Chinese relationship decayed. The discriminative process between the employers and the Chinese coolies became marked in the reign of King Rama V. After that the Chinese coolies established their own kongsi systems which were at first occupied by the employers or thaokae. The kongsi coolies at that time were not the kongsi production-on the contrary they were only the brokers of coolie laborers (Damrong Rachanuphap 1974: 332-336). At the same time the employers also established their own kongsi organization, "the Chinese Chamber of Commerce (1910)" or hui in the Chinese style (Bualek 2002: 242-243, 291).

Another reason for the change in the relationship was caused by the centralization or strengthening of the central state in King Rama V's reign. According to this concept, the kongsi system or angyi group were unlawful organizations so they had to be suppressed and abolished. Evidence from King Rama IV's era and King Rama V's era shows that the kongsi coolies frequently quarreled. This rivalry arose chiefly from competition over seeking jobs for newcomers. In Bangkok, thaokae groups derived great benefit from being coolie brokers, so they recruited a large number of coolies from China. In business competition they had to establish the 
kongsi systems for controlling their coolies and acquiring work; thus quarreling among the kongsi coolies occurred all the time. In the southern area, there were two prominent kongsi groups: Yi Hin and Pun Thao Kong. Both of them dealt in mining, so they fought for the control of water resources to clean the tin ore. The government at that time used the supporting angyi policy to solve kongsi disputes. According to this policy, the Chinese had some measure of selfgovernment so they had to choose leaders of each clan to have contact with the government. The Chinese leaders had to drink holy water and take an oath that they would be loyal to the king and not cause any disturbance. Explicitly, this policy collapsed because these leaders engaged in disputes after the death of the powerful aristrocrat, Somdet Chaophraya Borommaha Sri Suriyawong (Chuang Bunnag) in 1882 who had employed the supporting angyi policy. At that period the angyi kongsi groups lacked any person to respect and look up to so they frequently fought among themselves (Damrong Rachanuphap 1974: 334-365).

In 1889 in Bangkok, there was a big battle between a Teochiu kongsi group and a Hokkien kongsi groups because of the rivalry in seeking jobs for newcomers. The government used an army of about one thousand soldiers to suppress this disturbance. About eight hundred members of both kongsi groups were captured, thirty were killed and twenty injured. After this incident, the government definitely decided to end the Chinese kongsi angyi organization. The government proclaimed the angyi Act of 1887 prohibiting the establishment of the kongsi angyi organization. Those breaking the law were to be fined as well as detained for any infraction. After this, the
Thai state passed the Nationality Change Act of 1911, the Exile Act of 1912 and the Nationality Act of 1913 to control the Chinese community. Another important act was the Association Act of 1914 which compelled Chinese organizations of all kinds to register and come under the control of the Thai state ${ }^{3}$. These acts were an attempt by the Thai state to coerce the Chinese into conforming to Thai ways and involuntarily erode the Chinese kongsi system.

The other cause of the kongsi collapse was the European influence in both economy and culture. The growth of production and trade arising from European capitalism provided huge benefits to the Chinese capitalists and the rich in Thailand. This new group in Thai society needed a new way of life to demonstrate their wealth, so they replaced the Chinese life style with a European style. This weakened the Confucian brotherhood culture and the basis of the kongsi relationship became ignored. A lot of Chinese merchants and coolies accepted the Christian religion and became the responsibility of European consuls (Lertphanichkul 1981: 18241910). These were reasons for the Chinese kongsi decline.

4. This investigative research into the kongsi system in Thailand, has studied five specific cases. They are 1. shipping and ship-building, 2. the sugar industry, 3 . pirate organizations, 4. tin mines, and 5. various economic activities in the capital, Bangkok. The Chinese coolies played a major role in the pepper plant industry but there is insufficient data for an in-depth study, so it was not included in this research. Conclusions drawn from the five

\footnotetext{
${ }^{3}$ See Wichailak (1934a: 119-121, 1934b: 256259, 1934c: 165-172, 1935: 103-110)
} 
case studies may be summarized as follows:

4.1 Chinese people have played a significant role in the maritime affairs of Thailand since the Ayutthaya period. The junk trade between China and Ayutthaya, under the tribute system, was so prosperous that there was an organization named "Pen-kang hang" in Kwangtung to take care of the monopoly of maritime trade between the two kingdoms (Cushman 1975: 40-41). The destruction of the Ayutthaya state caused a short break in the trade cycle which was not revived until the time of King Rama II and King Rama III in the Rattanakosin era. Not only the king but also aristocrats and Chinese merchants took part in the trade. The main exports to China were rhinoceros horn, sappan wood, cardamoms, pepper, crude sugar, anchors, tillers and other jungle products. Thailand traded with its other neighbors in Southeast Asia, as well as with China. Crawfurd, who entered Thailand in about 1823 , noted that there were about seventy junks on the Chaophraya River, two of them were government-owned vessels, twenty were owned by aristocrats and about fourtyeight were owned by Chinese merchants. In addition to these, the Chinese merchants had about thirty to forty vessels trading with adjacent areas in Southeast Asia. All of the laborers and the commanders on the ships were Chinese. The maritime trade brought wealth to all who were involved in it and they were named chaosua or setthi samphao (Thinanont 1979: 66-73).

Burney observed in 1826 that the Siamese king and most of his courtiers participated in the trade with China, which yielded them a three hundred percent profit at least. They sold sapan wood, gamboge and other goods at Chinese ports via
Chinese merchants. According to documents of the Third Reign, Siamese vessels trading with Canton, Shanghai and Ningpo carried as their usual cargo, such items as sapan wood, pepper, red wood, bee's wax, tin, cardamom, rudders, rhinoceros horn and betel nuts. Between 1844 and 1845, twenty ships were involved in the transport of such items to the above destinations. We also learn that the cost of outfitting a junk to trade there, at least for that season, was slightly over one thousand three hundred and eighty Siamese tales (£690). Such ventures involved a number of junks from the Siamese side, including those vessels owned by resident merchants and chartered to the Siamese court. There were also many from the Chinese side which traded actively with Siam (Viraphol 1977: 194-195).

In the early Rattanakosin period, Bangkok was the hub of Chinese junk building because the junks built in Siam were considered to be the cheapest and most durable. The Chinese junks which were built in Bangkok imitated the style of the junks of Kwangtung and Fukien. Bangkok became the hub for Chinese junk building because there were considerable quantities of hard wood in this area so junks were fifty percent cheaper than those built in China. The shipping industry may have existed before the Rattanakosin period and evidence shows that in King Rama I's reign, there were many shipyards along the Chaophraya River. In King Rama II's reign the Thai shipping industry was very influential on the Asian shipping market (Cushman 1975: 81-82). According to Crawfurd's report, the majority of junks that journeyed between East India and China were built in Bangkok. Chinese merchants and the Thai government were the owners of the 
shipyards which were located in many of the kingdom's coastal areas. Crawfurd estimated that there were about eight thousand laborers working in shipping but he did not give any information on the number of coolies in the ship building industry (Crawfurd 1972: 111). A fair approximation might be that more than ten thousand laborers worked in the two activities due to prosperity at that time.

Labor in both shipping and ship-building used the kongsi system as in China. The research of Jennifer Wayne Cushman explains that everyone on the ship had a strong spirit of brotherhood and could expect a share of the profits. Because they were from the same village and they had collaborated in building ships, everyone was allowed a certain tonnage of personal goods on the ship which depended upon the position and the status of the person. Some of them could get salaries and also some space to hold goods but some could get only space (Cushman 1975: 137-139). This kind of relationship also existed on Thai ships. For the ship-building industry, labor relationship was in accordance with the kongsi system and depended on the dialectal groups which were Teochiu, Hokkien and Hainam, of which Hainam was the most important group playing a role in this industry.

The coming of the Europeans to this region from the reign of King Rama III onwards contributed to the decline of the shipping industry in Thailand. The junk trade and junk building were replaced by European merchant ships, which subsequently included steamships (Cushman 1975: 88 89).

4.2 Chinese piracy expanded over the south seas of China and Southeast Asia during the eighteenth and nineteenth centuries. The same kongsi tradition for sea life, was used for their selfgovernment. The reasons that the Chinese people in the south of China turned to piracy were much the same as their reasons for migration. In reality, the Chinese immigrants formed a closed, tightly-knit society and there were close relationships between merchants, immigrants and pirates. In the junks, they journeyed hoping for good fortune which might be any of three types, depending upon circumstances. These would determine whether the emigrants became good or bad because the seas at that time were not controlled by any one nation. During the period of the Opium War (1839-1842) and the Tai-Peng rebellion (1850-1864), many Chinese people turned to piracy. Some of the Chinese immigrants could not get any work because their number exceeded the requirements for regional production. Sometimes they met problems in new lands so they turned to piracy later on. It was easy to exist as a sea pirate because no states or kingdoms in Southeast Asia had a strong enough navy or army to suppress them.

The Chinese, who had menaced the seas around the Thai kingdom since the reign of King Rama III, can be separated into two groups: one consisting of the pirates intending to build their junks for plundering, and the other pirates who were sometimes merchants. These merchants would turn to piracy when they had the chance to attack other vessels and to smuggle merchandise. The two groups of pirates were found throughout the seas of Southeast Asia and this presented a great problem to the Western countries which were intruding into this region. Vessels from Great Britain, France, Holland, and America were frequently attacked, plundered and their merchandise 
stolen. These Chinese pirates created an enormous problem not only for the vessels of Western countries but also for Thai shipping.

In 1850, Chinese pirates perpetrated an egregious attack. They stormed the town of Songkhla, burnt the governor's house and captured the deputy governor. The officers and the people were so frightened that they escaped and hid in the jungle (see The Chinese). In the reigns of King Rama IV and King Rama V Chinese pirate activity increased especially in the area of the Andaman Sea because this was an area with many tin mines, merchant ships and multitudes of Chinese coolies. There appeared to be a correlation between the number of coolies and the incidences of piracy. When the tin price in the market failed, many tin mines were closed and, consequently, the unemployed Chinese coolies turned to piracy. Sometimes, the conflict between the Chinese kongsi increased the number of pirates and their activities. Each side both attacked and plundered the other as the opportunity presented itself. $^{4}$

The Thai state succeeded in suppressing the pirates in the reign of King Rama V because of the combined efforts of Great Britain, France, and the Thai government. Great Britain was the country that had suffered most from piracy. Its ships were frequently the target of attacks and this interrupted their commercial activity. The British government attempted to subdue the pirates in this region from the sea south of China to the Malaka Channel but British efforts to crush the pirates would

${ }^{4}$ see The Letter from Chaophraya Akharamahasenabordi to Phraya Senanuchit, the governor of Takao-Pra Province have failed without the cooperation of the Thai government. For this reason, the British government employed many strategies to influence the Thai government such as giving advice, sending naval troops to subdue the pirates along the Thai coast and severely condemning the Thai state. ${ }^{5}$ Subduing the pirates was the main reason that Thailand had to develop a navy.

4.3 The sugar industry, which emerged about 1810 at the beginning of the Rattanakosin period, was the earliest monopoly industry that employed huge numbers of Chinese coolies and attracted much investment. At that time, before the Bowring Treaty of 1855 , sugar was the most important export item even more so than rice. In 1832 it was recorded that the major areas of sugar plantations and mills were in the central part of Thailand near Bangkok, in the provinces of NakornPrathom, Samut-Prakarn, Nakorn-Chaisri, Samut-Sakorn, Ratchaburi and Chachoengsao. In this last province, on the Bang Pakong River, there were about thirty sugar mills. The prosperity of the sugar industry arose because of the support of the Thai government. The investors could be divided into three groups which were: 1 . The king and the members of the royal family, 2. The aristocrats or noblemen and 3. The Chinese merchants. The first and the second groups played their role in this industry by making capital available and giving the privileges to the third group. The patronage relationship was commonly used among the three groups of investors. The powerful aristocrat "Bunnag" family was significantly involved in the sugar

\footnotetext{
${ }^{5}$ see The Letter from Chaophraya

Akharamahasenabordi to Phraya Phuket
} 
industry. The Chinese merchants, the real businessmen in this industry, were also the same group that was investing in the junk trade and in sugar tax-farmers. In the reign of King Rama III, the sugar industry had been conducted as a monopoly by taxfarmers for the whole country. There was a change in the reign of King Rama IV in that the tax farming was separated into three regions and was also managed by three tax-farmers. Nevertheless, this business brought a lot of benefit to those involved (Burusratanaphand 1983: 10-20).

In the sugar mills and sugar cane plantations, there was a Chinese manager or longchu who governed the Chinese laborers. Normally, the sugar kongsi system formed according to dialectal groups; Teochiu, Hokkien and Hainam. The managers and the laborers were always from the same dialectal group. In each sugar mill, there were about 100-300 laborers. They spent their lives together, eating rice cooked in the same large cauldron, and sleeping under the same roof. The Chinese laborers had to obey the foremen and the managers and there existed a brotherly respect among members of the same kongsi group. In some sugar mills or plantations, their relationship was very deep at the clan level and they were, thus, tightly knit. For example, the "Tan" clan in Chachoengsao was very powerful because the top leader of the kongsi angyi organization in this area, longchu sin-tong, was in this clan. ${ }^{6}$

In 1848, there was a violent rebellion of the kongsi angyi organization in the sugar industry in Chachoengsao in which every

${ }^{6}$ see The testimony copy of a Chinese on the triad story in Chachoengsao Province sugar mill and plantation took part. The rebels killed the governor, and then occupied the town. Eventually, they were overcome by central state troops and about three thousand members were killed. The causes of the rebellion were dissatisfaction with official judgments and also the government's suppression of opium smuggling from which the kongsi group and the sugar managers had obtained benefit. In engaging kongsi troops to occupy the town, the kongsi warrior coolies had to completely obey their leaders or longchu under penalty of death if they refused. The ritual oath-taking ceremony and opium addiction were used as tools of persuasion and to create unity. The soldiers of the "Tan" clan were the most trustworthy so they took the major role in controlling the town. ${ }^{7}$

4.4 In the south of Thailand, Chinese coolies had played the major role as tin mine workers in the reign of King Rama III after the central state gave authority in tin mining concessions and the collection of revenues to the Chinese tax farmers. While King Rama IV was the ruler, there was another change in tin mining owing to the high demand for tin on the world market and the increase in the tin concession fee. The Chinese taxfarmers, who normally were also the town governors, had expanded their production area and recruited Chinese coolies. The Phuket governor had persuaded Chinese investors from Penang to participate in investment and to recruit coolies to work in Phuket. The central government had supported this arrangement by lending the

\footnotetext{
${ }^{7}$ See The testimony copy of a Chinese on the triad story in Chachoengsao Province
} 
tax-farmers capital because they expected an increase in income from tin revenues, trading revenues, tariffs and the Chinese poll tax phuk phi. Thanks to the Bowring Treaty 1855 , tin ore became a free trade item and the state could no longer levy any tax on it, which was a plus, even though the tin mining concessions were still in the governor's hands. The power of the governor in tin mining concessions was abolished in 1882, in accordance with the new rules from the central government as part of the change. A governor-general representing the central government was sent to govern the southern part and collect the revenues instead (Phongphatarawat 2000: 43-52).

Most of the Chinese coolies in the tin mines were Hokkien from Amoy province in China. At first, in King Rama III's time, they had come through Penang and Malaya. The Chinese coolies in the south of Thailand could be separated into two groups of voluntary or free immigrants and credit-ticket immigrants of which the free immigrants were numerically the larger. Credit-ticket migrants had to travel under brokers or agencies that had their branches in the rural areas of China. This group of coolie migrants increased in number when the tin mines' need for labor increased. At the time when the local governors had the concession authority in mining, they had financed the coolie brokers to recruit coolies from China to work in tin mines but after the central government sent the governor-general to rule the southern provinces directly, coolie recruitment was arranged by the opium tax-farmers with the central government financially supporting the transportation. The credit-ticket coolie system ended towards the end of King Rama V's reign, after which all coolies were free immigrants coming into the country through the persuasion of their cousins (Phongphatarawat 2000: 51-52).

The tin mine coolies lived their lives under the kongsi system. Most of them were single and worked with employers of the same clan so the brotherhood relationship was used to cover the distinction between the classes. Tin kongsi system was involved in the production area, the office, as well as in the dwelling places of both the employers and the coolies. Normally, in every tin kongsi group, there was a kongsi store for supplying everyday needs, an opium den, a gambling den and a liquor shop. It is estimated that each kongsi group had about one hundred coolies. The employer was the chief and enjoyed high respect. He could whip the coolies if they were considered lazy. Generally, tin employers had a close relationship with the town governors and they were not only the chiefs of the Chinese clans in the town but also the chiefs of the secret societies or angyi. In every kongsi group the employers had to provide opium, gambling dens, and liquor as a means of tempting the coolies staying in the kongsi house. These evils were also instruments that employers used to recoup wages already paid (Phongphatarawat 2000: 43-52).

Practically, Chinese coolies had to work ten hours a day and could have left from work on seven days for seven days a year on Chinese ceremonial days. In the case of sickness, they could have left their work for no more than thirty days a year. Voluntary coolies could earn 30-40 Malay ticals but credit-ticket coolies had to work for about one to three years without any wage to repay the cost of their ticket. They only received a wage after they had completed the repayment. Traditionally, the labor wage would be paid every six months after the employers had sold their 
tin ore, but if an employer suffered a loss, the coolies might not get any wage or get only half of it and this regularly caused friction in the tin mines (Auansakul 1979: 170-171).

Not only the tin mine employers but also the Thai government derived enormous financial advantage from the employment of coolies, so the government introduced a policy of increased recruitment of Chinese coolies. The government also received revenue from border pass tariffs, the Chinese poll tax phuk phi, opium and liquor taxes, and more besides. It has been estimated that in 1891 the government got forty baht from each Chinese and four to eight million baht in total from all the Chinese in the south of Thailand (Auansakul 1979). To control the Chinese coolies, the government employed a selfgoverning policy by choosing the leaders from the chiefs of the Chinese clans in the area. This policy made the employers, who were also the clan chiefs and the leaders of the secret societies, much more powerful in the eyes of coolies (Phongphatarawat 2000: 188).

The first secret society in Thailand was established in Phuket during the reign of King Rama II and it was a branch of the secret society in Penang which was settled in 1799. The objectives of these organizations were self-government, the protection of their interests, and opposition to the power of Great Britain. The secret societies in both Penang and Phuket were consistently at loggerheads. They had forsaken the ideals of the former secret societies in China to oppose the Manchoo dynasty and to recover the Ming dynasty. In the south of Thailand secret societies were divided into two big groups: the Yi Hin kongsi group and the Pun Thao Kong kongsi group, and they had branches in every tin mine. Normally, the branches linked up and helped each other when they had problems and sometimes they cooperated with the organizations in Penang (Lertphanichkul 1991: 149).

The secret societies in the south of Thailand were responsible for three significant events. The first, in 1867, was the conflict between the Yi Hin kongsi and the Pun Thao Kong kongsi in Phuket over the tin washing stream. The second, in 1876, in Ranong and Phuket, arose because tin mine employers had not paid the labor wage as the agreement had demanded. In that year the government increased the Chinese poll tax from forty cents to two ticals and sixty cents and the Chinese coolies felt that they had not received justice from the local governors. These problems culminated in a coolie uprising all over the southern part of Thailand. The third event occurred in 1878 when the Pun Thao Kong kongsi attacked Krabi town and killed the governor. This event highlighted the conflict between the leaders of the Chinese kongsi group with their interests, and the tin mine coolies who were used as instruments to protect the interests of each group (Lertphanichkul 1991: 179-182).

4.5 At the end of the nineteenth century, the Chinese coolies in rice mills, saw mills and public activities were most numerous in Bangkok as a result of the expansion of trading capitalism from the West. The Chinese coolies' lives in Bangkok differed from the lives of coolies in the provinces by virtue of their different working conditions and surroundings. The Chinese coolies in Bangkok were not restricted in their daily lives, and were not lonely and enclosed in the kongsi houses like the coolies in tin mines or sugar mills. The urban-dwelling coolies' lives were 
more open, even though some of them were still under the control of the kongsi angyi organization. At that time the kongsi system was challenged by state reformation and the development of the Thai royal army. The Thai state set about modernizing its infrastructure based on the European model and attempted to strengthen its central power. The lonely lives of the Chinese coolies had been changed after they had been able to take their women with them after the Chinese government allowed Chinese women to go abroad in 1893. Coolies were independent in making the decision to stay inside or outside the production area or to stay with their relatives. As opium use, they could take it outside the kongsi house in the opium dens which were located near the rice mills, the saw mills, the ship docks and in every Chinese community. At the same time, they were able to go to the gambling dens, the liquor shops and also the remittance shops in the town.

In 1909 the number of Chinese immigrants in Bangkok reached 162, 505 as is shown in the table below.

Table 2: The number of Chinese immigrants in Bangkok in 1909

\begin{tabular}{|l|l|l|l|}
\hline $\begin{array}{c}\text { Chinese } \\
\text { dialect }\end{array}$ & \multicolumn{1}{|c|}{ Male } & Female & \multicolumn{1}{|c|}{ Total } \\
\hline Teochiu & 78,091 & 8,207 & 86,298 \\
\hline Hokkien & 19,823 & 2,367 & 22,190 \\
\hline Kwangtung & 25,978 & 4,151 & 30,129 \\
\hline Hainam & 12,165 & 903 & 13,068 \\
\hline Hakka & 9,411 & 1,409 & 10,820 \\
\hline Total & 145,468 & 17,037 & 162,505 \\
\hline
\end{tabular}

(The number of Chinese in Bangkok Rattanakosin Sok)

However, in King Rama V's reign, almost all of the Chinese coolies were still under the control of the secret societies or angyi which were divided into three significant groups; Neeg-heng, Sew Leegure and Neeg-hoge. Neeg-heng kongsi group assembled the rice mill coolies, Sew Leegure kongsi group collected the cargo vessel coolies and Neeg-hoge kongsi group gathered the coolies working in the town shops. All three had the same objective of protecting the kongsi interior especially in coolie trading. The leader of a kongsi system was called a thaokae and acted as the coolie broker. The kongsi system were able to control their coolies since they traveled from China. In some kongsi system, there might be agencies in the local villages to take the coolies to Thailand. After they arrived in Bangkok, the thaokae people would arrange jobs for them. As compensation for these arrangements, thaokae people would receive the profit from the credit ticket, expenses during the voyage, customs tariffs, food and accommodation in kongsi system (Damrong Rachanuphap 1974: 332-334). All of the expenses, together with high interest, would be taken from the laborers' wages usually for a threeyear period. The starvation coolies had to be under the patronage of kongsi angyi organizations because only by this way could they get a job and be protected from any harm in the new land.

Rice milling was the main economic activity and employed numerous Chinese coolies at that time. There were three groups of investors in this business; European traders, the Thai upper class (The king and his relatives as well as aristocrats) and Chinese traders. In the rice mills, longchu or the rice mill managers had the duty to control both the productivity and the laborers. The real investors resided in their luxurious private houses outside the production area so that the difference between the classes, 
employers and employees, became explicit. Coolies in the rice mills were divided into two groups. The first were salary workers who received both salary and accommodation in the rice mills. The others were the contemporary workers who got only labor wages depending on their output of work and these were the larger portion of the coolies in the rice mills. The contemporary workers were free to work in any place but they had to be under the control of coolie brokers. Normally, Chinese coolies worked and were under the control of the same Chinese dialectal group as themselves (Tana 1984: 35-36).

Many newly-arrived, unskilled and generally illiterate coolies were employed on Bangkok public works such as building the roads and the railways as well as the tramway. Most of the coolies in public works were under the control of coolie brokers or thaokae. Some of them worked pulling rickshaws, feeding pigs and ducks and cultivating vegetables. All of them were the lowest class of coolies in Bangkok working for low wages so they had difficult lives. The coolies employed in building railways worked in bad and dangerous condition and consequently many of them died during this hard work. For efficiency in controlling the coolies and rivalry for work, thaokae people always organized the kongsi angyi organizations, so, even though this coolie control system was out of date, it was still maintained in Bangkok.

The principal uprisings of coolies in Bangkok occurred twice in the reign of King Rama V. The first occurred in 1889 and was the result of the conflict between two groups of angyi; the sew leegue and the ngee heng over the problem of seeking jobs. On this occasion, each group had about a thousand coolies participating and during the riot they closed the Charoenkrung Road from Yannawa to Bangrak for two days. The Thai government had to use soldiers and sailors from the Thai royal army and navy to suppress them. After the event the Thai government determined to abolish the secret Chinese societies, and in 1887 they passed the angyi Act to subdue the Chinese kongsi angyi organizations. To disempower all groups outside the central government was the crucial element of state reformation to centralize power within an absolutist state (Damrong Rachanuphap 1974: 353-365).

The second uprising was in 1910 and, again, it was a conflict between the Chinese coolies and the central state. The cause of this conflict came from the states increasing of the Chinese poll tax phuk phi from four baht per three years to six baht per year. The Chinese coolies in Bangkok, especially in the rice mills, saw mills and on the piers at that time, were under the control of secret societies. Estimates suggest that there were about ten-thousand coolies in Bangkok participating in this event. About twenty-thousand government soldiers were employed to suppress and control every section of the Chinese community along the Chaophraya River and the Charoenkrung Road. The government exiled some of the prominent rioters in this event. However, the government believed that the notorious secret society leader of Bangkok Yi Ko Hong, who was also the big lottery tax farmer of Bangkok, was the man behind the scene. Moreover, the government also confidently believed that the French consul supported Yi Ko Hong 
in this act of revolt against the Thai government. $^{8}$

The failure of the uprising on the second occasion signaled the end of the kongsi angyi system and the old Chinese leadership style. The success of the suppression added to the strength of the royal Thai army under the absolute monarchy. After this event, the government proclaimed the Exile Act 1912 and the Association Act 1914 to control any further riots and outlaw organizations. In addition, the government planned to reduce Yi Ko Hong's role in the lottery tax. In 1916-1917 the government succeeded in taking all gambling businesses from the Chinese tax farmers and ran these itself. These measures spelled the decline and the end of the kongsi angyi organizations and their leaders. There was no longer any large kongsi angyi organization; on the contrary only numerous small gangster organizations remained. This marked the end of the era of laborers working under the control of the kongsi system.

\section{References}

Auansakul, Punnee. 1979. Tin Mining Industry and Economic Change in Southern Thailand 1868-1931 (กิจการ เหมืองแร่ดีบุกกับการเปลี่ยนแปลงทางเศรษฐกิจ ภาคใต้ พ.ศ. 2411-2474). M.A. thesis, Chulalongkorn University. (In Thai)

\footnotetext{
${ }^{8}$ National Archives, Bangkok, Ratchakan thi 6 (th Reign) Nakornban 25.2 (Ministry of City) /Chin Nut Yood Nagn (The Chinese Boycott)
}

Bualek, Punnee. 2002. The Nature of Thai Capitalists from their Flourishing to Declination 1914-1939 (ลักษณะของ นายทุนไทยในช่วงระหว่าง พ.ศ. 2457-2482 บทเรียนจากความรุ่งโรจน์สู่โศกนาฏกรรม). Bangkok: Pantakit. (In Thai)

Burusratanaphand, Walwipha, M.L. 1983. The Sugar-Cane Cultivation and Sugar Industry in $19^{\text {th }}$ Century (การ เพาะปลูกอ้อยและอุตสาหกรรมน้ำตาลไทยใน คริสต์ศตวรรษที่ 12). Bangkok: Thai Khadi Research Institue, Thammasat University. (In Thai)

Chanthawanich, Supang. 1991. The Homeland of Teochiu Chinese in Thailand (ถิ่นกำเนิดของชาวจีนแต้จิ๋ใน ประเทศไทย). In The Teochiu Chinese in Thailand and Their Homeland in Chaoshan: The First Period at Zhanlin Port (1767-1850) (ชาวจีนแต้จั๋วในประเทศ ไทยและในภูมิลำเนาเดิมที่เฉาซัน สมัยที่หนึ่ง ท่าเรือจางหลิน (2310-2393)). Bangkok: Institute of Asian Studies, Chulalongkorn University. (In Thai)

Chew, Daniel. 1990. Chinese Pioneers on the Sarawak Frontier 1841-1941. Singapore: Oxford University Press.

Campbell, Persia Crawford. 1971. Chinese Coolie Emigration to countries within the British Empire. London: Frank Cass.

Crawfurd, John. 1972. The Crawfurd Papers, translated in Thai by Pairoj Kedmaenkit. Bangkok: Kromsinla- 
pakorn.

Cushman, Jennifer Wayne. 1975. "Fields from the Sea: Chinese Junk Trade with Siam during the Late Eighteenth Century and Early Nineteenth Century." Ph.D. Dissertation, Cornell University.

Damrong Rachanuphap, Somdet Kromphraya. 1974. Ang-yi (อั้งยี่). In The Old Legend (นิทานโบราณ). Bangkok: Khanwitaya.

Iawsriwong, Nithi. 1995. Pak Kai Lae Bai Rua (ปากไก่และใบเรือ). $2^{\text {nd }}$ edition. Bangkok: Amarin.

Irick, Robert L. 1982. Ch'ing Policy toward the Coolie Trade 1847-1878. Taipei: Chinese Material Center.

Jaranpattana, Supaporn. 1980. Opium Revenue and Fiscal Policy of Thailand 1824-1925 (ภาษีฝิ่นกับนโยบายด้านการคลัง ของรัฐบาลไทย พ.ศ.2367-2468). M.A. thesis, Chulalongkorn University. (In Thai)

Lertphanichkul, Suparat. 1981. Triad Societies in Thailand 1824-1910 (สมาคมลับอั้งยี่ในประเทศไทย พ.ศ. $2367-$ 2453). M.A. thesis, Department of History, Chulalongkorn University. (In Thai)

---. 1991. The Chinese Governing in Rattanakosin before the Reformation Period 1782-1892 (การควบคุมชาวจีนใน สมัยก่อนการปฏิรูปการปกครอง). In The Teochiu Chinese in Thailand and Their Homeland in Chaoshan: The First
Period at Zhanlin Port (1767-1850) (ชาวจีนแต้จิ๋วในประเทศไทยและภูมิลำเนาเดิม ที่เฉาซันสมัยที่ 1 ท่าเรือจางหลิน (2310-2393)). Bangkok: Institute of Asian Studies, Chulalongkorn University. (In Thai)

Phalokin, Wannee. 1995. The Importance of the Market-oriented Production of Chachoengsao Province in Bangkok Period before the Bowring Treaty (ความสำคัญของการผลิตเพื่อการค้าของเมือง ฉะเชิงเทราในสมัยรัตนโกสินทร์ก่อน สนธิสัญญาบาวริง). M.A. thesis, Srinakharinwirot University. (In Thai)

Phongphatarawat, Nuansri. 2000. The Roles of the Fukeinese Leaders in Phuket 1853-1932 (บทบาทผู้นำชาวจีน ฮกเกี้ยนในเกาะภูเก็ตระหว่าง พ.ศ.2396-2475). M.A. thesis, Srinakharinwirot University. (In Thai)

Skinner G. William. 1957. Chinese Society in Thailand: An Analytical History. New York: Cornell University Press.

Swee, Sao Lin. 1991. Ch'ing Policy on the Overseas Chinese (นโยบายชาวจีน โพ้นทะเลก่อนราชวงศ์ชิง). In The Teochiu Chinese in Thailand and Their Homeland in Chaoshan: the First Period at Zhanlin Port (1767-1850) (ชาวจีนแต้จิ๋ในประเทศไทยและภูมิลำเนาเดิม ที่เฉาซันสมัยที่ 1 ท่าเรือจางหลิน (2310-2393)), translated in Thai by Sawai Visawanun. Bangkok: Institute of Asian Studies, Chulalongkorn University. (In Thai)

Tana, Thanom. 1984. Rice Mills Operation in Central Thailand 1858 
1939 (กิจการโรงสีข้าวในที่ราบภาคกลางของ ประเทศไทย พ.ศ. 2401-2481). M.A. thesis, Silpakorn University. (In Thai)

The Chinese Pirates Pundered Songkhla

Town (จีนสลัดพรุนเมืองสงขลา). The

Fourth Reign Record: Lesser Era $1213 / 30$ (จดหมายเหตุรัชกาลที่ 4 จุลศักราช

1213/30). National Library, Bangkok (in Thai)

The Letter from Chaophraya

Akharamahasenabodi to Phraya Phuket (จดหมายจากเจ้าพระยาอัครมหาเสนาบดี ถึง พระยาภูเก็ต). National Archives, Bangkok. (in Thai)

The Letter from Chaophraya Akkharamahasenabodi to Phraya Sena $\mathrm{Nu}$ Chit, the Governor of Takua Pa Province (จดหมายจากเจ้าพระยาอัครมหา เสนาบดี ถึง พระยาเสนานุชิต ผู้ปกครองเมือง ตะกั่วป่า). National Archives, Bangkok. (in Thai)

The Number of Chinese in Bangkok Rattanakosin Sok (จำนวนชาวจีนใน กรุงเทพ สมัยรัตนโกสินทร์ศก). National Archives, Bangkok. (in Thai)

The Testimony Copy of a Chinese on the Triad Story in Chachoengsao Province. Chodmaihet (จดหมายเหตุ). National Library, Bangkok. (in Thai)

Thinanont, Waraporn. 1979. Junk Trade of Thailand in the Early Bangkok Period (การค้าสำเภาของไทยสมัย รัตนโกสินทร์ตอนต้น). M.A. Thesis,
Chulalongkorn University. (In Thai)

Trocki, Carl A. 1990. Opium and Empire: Chinese Society in Colonial Singapore 1800-1900. New York: Cornell University Press.

Veeskul, Aek. 1949. The Commercial Shipment of Thailand, The Memorandum Book in the Cremation Ceremony of Poe Sarapaiwanit (การ เดินเรือพาณิชย์ในประเทศไทย, หนังสือที่ระลึก ในงานฌาปนกิจศพนายโป๋ ศราภัยวานิช ณ วัด มกุฎกษัตริยาราม). (In Thai)

Vichairak, Sathian. (ed.). 1934a. The Exile Act 1912 (พระราชบัญญัติเนรเทศ พ.ศ. 2455). The Collection of Thai Laws: Volume 25 (ประชุมกฎหมายประจำศก เล่ม 25). Bangkok: Daily Mail Press. (in Thai)

---. 1934b. The Nationality Act 1913 ( พระราชบัญญัติสัญชาติ พ.ศ. 2456). The Collection of Thai Laws: Volume 26 (ประชุมกฎหมายประจำศก เล่ม 26 ). Bangkok: Daily Mail Press. (in Thai)

---. 1934c. The Association Act 1914 (พระราชบัญญัติสมาคม พ.ศ. 2457). The Collection of Thai Laws: Volume 27 (ประชุมกฎหมายประจำศก เล่ม 27). Bangkok: Daily Mail Press. (in Thai)

---. 1935. The Ang-yi Act of 1887 (พระราชบัญญัติอั้งยี่ พ.ศ. 2430). The Collection of Thai Laws: Volume 16 (ประชุมกฎหมายประจำศก เล่ม 16). 
Bangkok: Daily Mail Press. (in Thai)

Viraphol, Sarasin. 1977. Tribute and Profit: Sino-Siamese Trade 1652-

1853. Cambridge, Massachusetts:

Council on East Asian Studies, Harvard

University.

Wang, Tai Peng. 1995. The Origins of Chinese Kongsi. $2^{\text {nd }}$ edition. Selangor Darul Ehean, Malaysia: Pelanduk.

Yen, Ching-hwang. 1985. Coolie and Mandarins: China's Protection of Overseas Chinese during the Late Ch'ing Period (1851-1911). Singapore: Singapore University Press. 